\title{
Sustainable Development Strategy for Improving the Competitiveness of Oil Palm Industry
}

\author{
Bambang Aria Wisena, Arief Daryanto, Bustanul Arifin, and Rina Oktaviani \\ Graduate Program of Management and Business - Bogor Agricultural University (IPB)
}

\begin{abstract}
ART I C LE INF O
Keywords:

Sustainable Development, Competitiveness,

Oil Palm,

Environment,

Social, Economic.

\author{
A B S T R A C T
}

In the Oil World 2014 report, Indonesia is the world's largest palm oil producer with production of 28 million tons in 2014. Due to increasing market demand for palm oil, environmental and social issues are becoming more essential. This situation requiring a strategy and a policy that is able to balance between the increases of the economic benefits of production while the environmental and social impacts should be minimized. This study aims to identify and describe strategies and policies related to the development of the oil palm industry and its implementation at some companies in Indonesia and to identify factors affecting the competitiveness of the oil palm industry. This study uses ISM (Interpretive Structural Modeling) analytic method with the panel experts of oil palm industry stakeholders from the corporate, government, association, environmental NGOs and academia as respondentts. The results show that the strategy is carried out on the development of a sustainable oil palm industry should increase the attention to the environmental and social aspects with regard to economic aspects. Factors of social, environment, and law enforcement by the government are the most important factors of the strategies.
\end{abstract}

\section{INTRODUCTION}

Indonesia is a major $\mathrm{CPO}$ producing country with the world's highest volume of 28 million tons per year, followed by Malaysia and Thailand. Indonesian palm oil industry has a variety of advantages, primarily due to lower production costs and a very strategic position in the center of the world CPO industry in the South East Asia.
Oil palm development in Indonesia indicates that the industry has a positive prospect, particularly in relation to the added value and competitiveness. However, the development of oil palm industry is also facing various issues related to technological problem, economic, social, environmental, and governance which are getting more complex. Thus sustainable and equitable oil palm development 
can be accomplished in case not to distort the competitiveness of Indonesian oil palm products in the worldwide market (Bappenas 2010).

The implementation of sustainable development of palm oil industry is facing more obstacles and challenges, Thus the clear and unequivocal policies on the management of oil palm plantations need to be formulated, to ensure all stakeholders obtained benefits from the new strategy of sustainable development in palm oil industry.. Steps taken by the stakeholders in oil palm industry to harmonize community interests, maintain environmental sustainability and market demand which urges to produce palm oil in a sustainable manner is to form the Roundtable on Sustainable Palm Oil (RSPO). However, the formation of RSPO is also causing controversy from several major NGOs in the world. The formation of RSPO does not mean that oil palm industry has no more challenge (RSPO 2009).

In addition, Indonesian government policies related to the oil palm industry and plantations are still questionable. Particularly those related to the law enforcement, bureaucracy and even EIA (Environmental Impact Assessment) are still low, thus Indonesia is yet to be ready and losing competitiveness compared to Malaysia. To date, Malaysia has been selling a variety of derivative products with higher added value, while Indonesia is still dominated by crude palm oil (CPO) export. Whereas it does not mean that Indonesia is unable to produce various palm oil derivative products, but it is yet to be supported by a conducive policies. This study examines the principles of sustainable development strategies in the development oil palm industry in Indonesia, and formulates business and policy strategies to achieve sustainable competitive advantage of oil palm industry.

The implementation of sustainable palm oil industry in Indonesia was reflected by the forming of Indonesian Sustainable Palm Oil System (ISPO) which was a policy taken by the government of Indonesia, in this case Ministry of Agriculture with the goal to increase the competitiveness of palm oil of Indonesia in the world market and to participate in the fulfilling the commitment of President of Republic of Indonesia to reduce the glass house gas and to give attention toward the environmental problems. The application of ISPO would be done by holding firmly the principle of establishment and advocacy as well as guidance to the oil palm plantation which was the task of the government. Various regulations to administer the oil palm industry had been set by the government. The regulation aimed at maintaining the comfort of every actor in the development of oil palm industry, including about the perservation of the environment. In the implementation of the sustainable oil palm industry, Indonesia adapted various regulations set by RSPO and ISPO, to be adjusted with the condition of oil palm industry in Indonesia. Indonesia as the biggest producer of $\mathrm{CPO}$ in the world still felt the discrimination on its implementation.

Various regulations about the oil palm set by the world institution and government could not afford yet to develop the oil palm industry starting from the upstream to the downstream maximally. The competitiveness of oil palm industry in Indonesia could still be increased compared to other countries, especially Malaysia having the fewer oil palm land than Indonesia but having the superiority in other fields.

In relation with the sustainable development and the development of oil palm industry as well as the factors influencing the strategy of the competitiveness of oil palm industry in Indonesia, this research was focused on the topic of "Sustainable Development Strategy to Improve the Competitiveness of Oil Palm Industry". Where the research scope was in form of the formulation of development model of oil palm industry with the method of ISM (Interpretive Structural Modelling), so that the objective of this research was to identify 
and to describe the strategy and policy in relation with the development of oil palm industry and its implementation in some companies in Indonesia as well as to identify the factors influencing the oil palm industry.

This article aimed to map some elements influencing the sustainable development strategy to increase the competitiveness of oil palm industry in Indonesia. Then, this article also formulated the policy which needed to be taken based on the result of analysis of ISM in the research done.

\section{Development of Sustainable Oil Palm Industry}

Oil palm has the important role in the economy of Indonesia and is one of the mainstay commodities in producing the country' $s$ foreign exchange. In the period of 2010-2014 Indonesia is projected to be able to get the foreign exchange of US $\$ 80.9$ billion from the export of commodity of CPO. Based on the data from Directorate of Plantation - Ministry of Agriculture in 2011, it is found out that the total area of the national oil palm plantation land up to the end of 2010 reaches 7.16 million hectares, consisting of 3.3 million hectares of area of smallholder's estate and 3.8 million hectares area of private plantation and BUMN. The estimation of the total area of oil palm area in Indonesia in 2013 reaches 9.15 million hectares (Ditjenbun 2013).

The prospect of oil palm development is expected to be excellent, in terms of demand. It is expected that the demand for oil palm products will remain high in the future. This is due to a relatively high preference for palm oil compared with its substitution products such as soybean oil, corn oil and sunflower oil. The high preference for palm oil is due to many advantages over its substitute products. These advantages include, palm oil is relatively more durable, resistant to high pressure and temperature, not easily turns into rancid., Palm oil has high nutritional content, as well as useful as a raw material for various types of industries.

Other advantages are in terms of productivity and production costs. Palm oil has a relatively higher productivity and has relatively lower production costs compared to other vegetable oils such as soybean oil and sunflower seed oil. Palm oil production can exceed 3.5 tons per hectare, while soybean oil is only 0.4 tons per hectare, while sunflower seed oil is merely 0.5 tonnes per hectare. In terms of production costs, the average production cost of soybean oil is US $\$ 300$ per ton, while the average production cost of palm oil is only US $\$ 160$ per ton. In addition, Indonesia also has a comparative advantage in terms of relatively lower labor costs at $55 \%-60 \%$ compared to Malaysia (TAMSI-DMSI 2010).

Sustainable oil palm development is one part of the development of plantation and the national agriculture processing industry. The sustainable oil palm development covers the production increase, the productivity, the quality, the added value and the competitiveness, the income and the community welfare. Besides, the development of sustainable oil palm industry also covers the increase of foreign exchange of the country from the sub-sector of plantation, the availability of raw material for food and non-food industries including biodiesel, the management of resources wisely and sustainably as well as supporting the development area.

\section{Theory of Sustainable Development}

Based on Brundtland Report published by World Commission on Environment and Development (1987), the definition of sustainable development (SD) which is often quoted is: The development is fulfilling the need at the moment without reducing the ability of future generation to fulfill the need (Robertson 2005; Strange and Bayley 2008; Anderson 2010). The definition which is simpler but firm about the sustainable development is: "Saving the planet and erasing the poverty from the world (Kane 2010). Then with being guided by the concept of Triple Bottom Line (Elkington 1997), the development of sustainable oil palm industry can be seen from various aspects, i.e. economic 
aspect, social aspect, and environmental aspect. The three aspects of SD are seen from Figure 2.

Sustainability Triangle is by Fritz \& Schiefer (2008). This concept is also developed to become the concept of 3P: Profit - People - Planet which have been included in the charter of PBB (Manggabarani 2011).

The three aspects of sustainable development in general have the responsibility meaning as follows (Blackburn 2007):

- Success of Economy: the use of financial resources wisely for the welfare of company and for the welfare of community.

- Social Responsibility: to appreciate the human with: appreciating the employee; the practice of fair recruitment, anti-discrimination, nonexploitative; the responsible management toward the risk, idolizing the business ethics and law; appreciating the stakeholders, including the local community, investors, supplier and other; fair dealing with customer.

- Responsible for Living Environment: to appreciate the living and the management and use of natural resources wisely covering:
Conservation of resources, management and waste prevention, control and restoration of environment risk, lessening the supply chain impact and the collaboration with community.

Palm oil is the vegetable oil coming from the oil palm fruit, used both for food and non-food consumption. Total production of palm oil in the world is estimated more than 45 million ton, with Indonesia and Malaysia as the main producer and exporter in the world. The main importers are including India, China, and European Union.

Total production of palm oil in the world increases almost three times for the last 3 decades to 2010 . In 2010, the total production of palm oil has reached 45.86 million ton, with Indonesia and Malaysia dominating more than $85 \%$ of the total of the world. Indonesia and Malaysia each produce more than 21.5 million ton and 17.8 million ton of palm oil (LMC 2011). Total trade of palm oil and palm kernel oil reach more than 39 million ton, imported and exported. The main exporters of palm oil are Indonesia and Malaysia which each exports 15.7 and 15.1 million ton. The main importer countries are India, China, and European

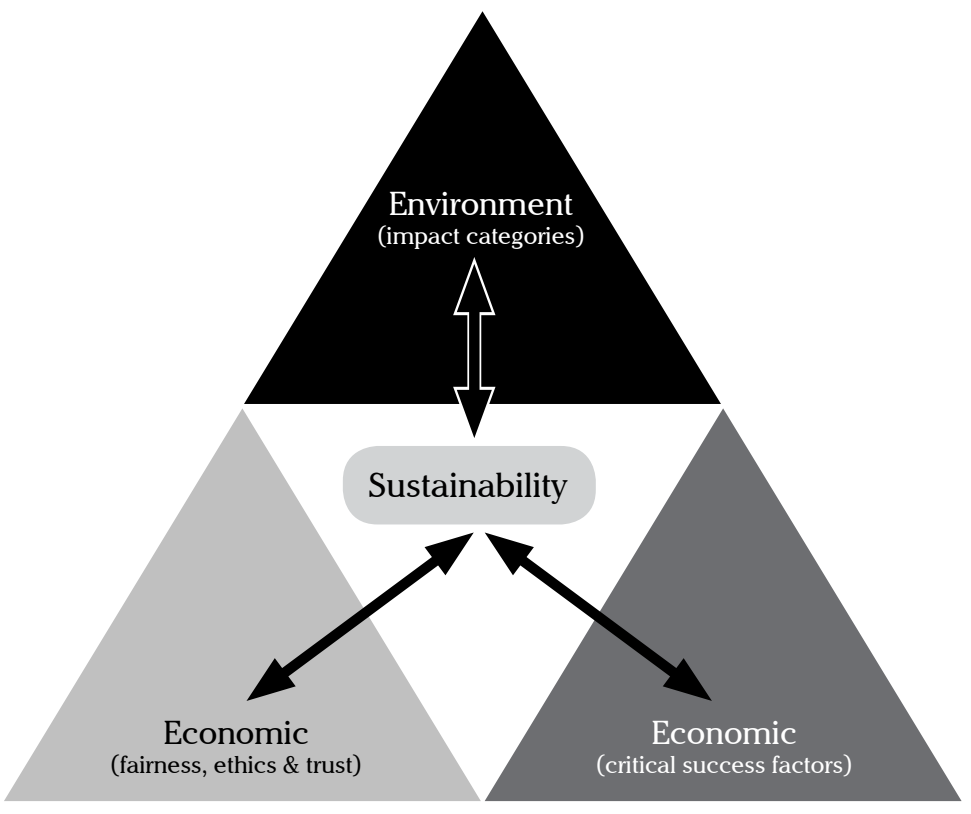

Figure 1. Sustainability triangle (Fritz \& Schiefer 2008) 
Tabel 1. Development of vegetable oil consumption in the world in the years of 1995/1996$2013 / 2014$ (in million metric ton).

\begin{tabular}{lcccccccccc}
\hline \multicolumn{1}{c}{ Vegetable Oil } & $\mathbf{9 5 / 9 6}$ & $\mathbf{0 5 / 0 6}$ & $\mathbf{0 6 / 0 7}$ & $\mathbf{0 7 / 0 8}$ & $\mathbf{0 8 / 0 9}$ & $\mathbf{0 9 / 1 0}$ & $\mathbf{1 0 / 1 1}$ & $\mathbf{1 1 / 1 2}$ & $\mathbf{1 2 / 1 3}$ & $\mathbf{1 3 / 1 4 ^ { * }}$ \\
\hline Oil Palm & 15.8 & 35.3 & 37.7 & 39.4 & 42.1 & 44.5 & 47.9 & 50.9 & 54.3 & 56.3 \\
Soybean Oil & 19.7 & 33.6 & 35.6 & 37.5 & 36 & 38.3 & 40.7 & 41.3 & 42.5 & 44.4 \\
Canola Oil & 11.2 & 16.9 & 17.6 & 18.3 & 20.1 & 22.4 & 23.5 & 23.8 & 23.6 & 24.5 \\
Sunflower & 8.6 & 9.8 & 10.3 & 9.4 & 10.6 & 11.4 & 11.8 & 13.1 & 13.6 & 14.5 \\
Kernel Oil & & & & & & & & & & \\
Other & 16.4 & 19.8 & 20 & 20.5 & 20.9 & 21.2 & 22.5 & 23.7 & 23.9 & 24.2 \\
\hline
\end{tabular}

*: estimation

Source: www.statista.com 2014

Union, which each imports 6.7 million, 6.3 million, and 4.6 million ton. Table 1 contains about the development of vegetable oil consumption in the world in the years of 1995/1996-2013/2014.

\section{Previous Research Analysis}

Indriantoro (2010) conducts the research about the analysis of production value chain of sustainable palm oil, the case study in PT. Hindoli. The purpose of this study is 1) Identify the environmental friendly competence from every chain in the oil palm plantation and industry of PT. Hindoli. 2) Identify the actor and the criteria influencing the chain value of the oil palm plantation and industry of PT. Hindoli. 3) Compose the performance of value chain which is possible in the oil palm plantation and industry of PT. Hindoli. 4) Make the alternative strategy for increasing the quality in every value chain in the oil palm plantation and industry of PT. Hindoli based on the principle of RSPO.

The result from this analysis is the application of environmental friendly program in accord with the certification of RSPO, where the priority of alternative strategy is the law and regulation aspects. The respondents have opinion that the thing will increase the quality and productivity which then is expected to increase the income both for the company and the plasma oil palm farmer. Through the application of environmentally friendly program which is realized in the certification of RSPO, the company is expected to be able to give training, guidance or application of the environmentally friendly for the plasma farmer. Some business of quality increase and productivity of palm oil production through the application of environmentally friendly program are: (a) to obey the national and international law and regulation which are appropriate and have been ratified; (b) to conduct the campaign of the role of oil palm plantation in the contribution of the application of carbon and oxygen provider; (c) to implement the operational procedure exactly and monitored consistently.

The position of oil palm company in Indonesia in the competition in the market is facing the other oil palm producer countries and also must compete with other vegetable oil outside of oil palm. It should be analyzed how is the position of Indonesia in form of the competitive map which considers the influencing factors.

Rifin (2010) revealed that between Indonesia and Malaysia should collaborate to promoted the use of palm oil to the buyers, because every addition of world demand would be profitable for both countries. Indonesia and Malaysia can collaborate in the market development, either in form new markets or uses of palm oil for new things such as biodiesel. In the long term, Indonesia should be able to differentiate the oil from its palm oil 
product from Malaysia to obtain the bigger market segment. With the competitive map of oil palm in Indonesia, it can be obtained the factors which become the priority to face the competitors both fellow oil palm producers and toward other vegetable oil producers.

Saragih (2010) emphasized that the superiority of Indonesia from the offering side has not guaranteed the success in the international business. With the liberalization of the international trade, the tight competition will occur in the international agribusiness product market. In the tight competition, the competitive advantage will become the determining factor in winning the competition. Therefore, to build and increase the competitive advantage of national agribusiness is very crucial starting now to the future. Further, Saragih emphasized that the actor should have the comprehensive knowledge about the change of consumer preference which is and will be happening.

\section{METHODS}

This research is the result of judgement of the experts determined purposively through focus group discussion (FGD) and questionnaire. The experts involved are of 15 people. This research uses the method of ISM (Interpretive Structural Modelling). ISM is the analytical tool aiming to plan the strategic policy. ISM analyzes the system elements and solves them in form of the graphic from the direct relation between element and hierarchical level. The elements can be in form of the policy purpose in the oil palm industry, the target or hope that will be achieved in the oil palm industry, and the evaluation factors related to the measurement of the policy effectiveness applied in this industry. While the direct relation can be in the varying context.

The application of sustainable development strategy on the competitiveness of oil palm industry is composed based on the result of basic assumptions with the highest priority as the requirement which should be paid attention in composing the policy model. The structure of the system of the element of the policy model of SD toward the competitiveness of the oil palm industry is analyzed with the method of ISM, and with the interview result to the experts 10 main elements which should be paid attention in making the policy are obtained i.e.: 1). Influenced institution/group, 2). Involved institution/group, 3). Need of program, 4). Main constraint, 5). Enabling change, 6). Objective, 7). Benchmark for reaching the goal, 8). Indicator of economic dimension, 9). Indicator of environmental dimension, 10). Indicator of social dimension. The evaluation of expert toward the contextual relation between sub-elements of involved institutions/groups is conducted by the approach of $\mathrm{V}, \mathrm{A}, \mathrm{X}$ and $\mathrm{O}$. This approach is used for obtaining the direct relation and the hierarchical level of contribution in the group of stakeholders. Every value of individual expert opinion is conducted in aggregation to obtain the mixed opinion value. This approach is also valid for other elements.

\section{RESULTS AND DISCUSSION}

\section{Element of influenced institution or group}

The verification in the element of influenced institution/group, becoming the key element, is Government (Policy, infrastructure, ISPO) (5) because it has the biggest driver power with the level of dependence toward the sub-element of other influenced group which is the lowest. Next, in the second rank, they are Investor (public, individual, institution) (3), Customer (domestic market, import) (2), Industry (upstream, downstream, supporting) (1), Financial institution (Bank, non Bank) (7), Pressure group (ISPO, NGO, other world institution) (8). The third rank are Research and Development (9) and Educational institution (6), while the fourth and fifth ranks are Farmer (self-supporting, plasmaa, big and small businesses) (4) and Public (11) which are the elements with the smallest impetus power with the highest level of dependence toward the group of stakeholders. The structure of the system 
of the element of the influenced institution/group with sustainable development policy toward the competitiveness of oil palm industry can be seen in Figure 2.

The Figure 2 shows that the level determining from every sub-element set from each rank of subelemen. The result of this research is obtained five hierarchies where the sub-elements of Public (11) and Farmer (4) occupy the level 1 and the level 2, while Government (5) occupies the fifth level. The sub-element of Government (5) is the subelement having the biggest influence as the key element and giving the highest level toward the sub-element under it.

\section{Element of involved institution or group}

Element or institution involved in the policy model of SD toward the competitiveness of oil palm industry consists of 11 sub-elementts, i.e. 1). Industry, 2). Customer, 3). Investor, 4). Farmer, 5). Government, 6). Education institution, 7). Financial institution, 8). Pressure group, 9). Research \& Development, 10). Consultant, 11). Public.

The verification in the element of involved institutions/groups which are becoming the key sub-elements are Pressure group (ISPO, NGO, other world institutions) (8), Government (policy, infrastructure, ISPO) (5), and Farmer (selfsupporting, plasmaa, big and small businesses)

\section{Level}

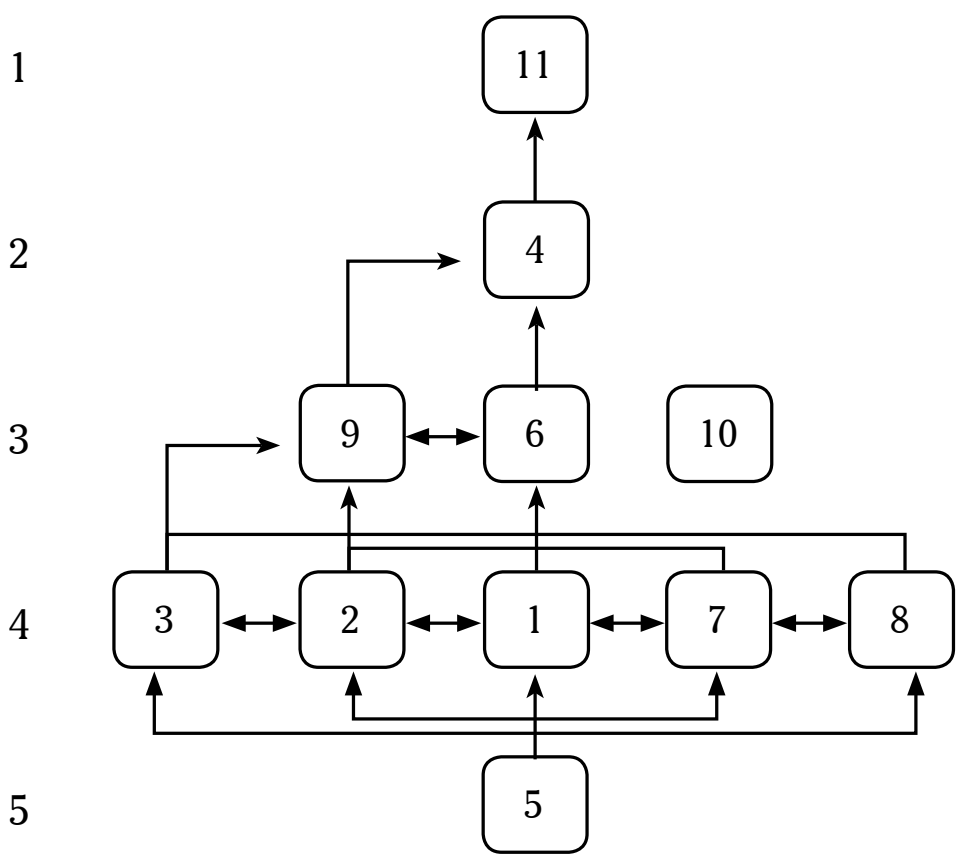

Figure 2. Structure of the system of the element of influenced institution/group

Notes:

1. Industry (upstream, downstream, supporting)

2. Customer (domestic market, import)

3. Investor (public, individual, institution)

4. Farmer (self-supporting, plasma, big and small businesses)

5. Government (policy, infrastructure, ISPO)

6. Educational institution
7. Financial institution (bank and non bank)

8. Pressure group (ISPO, NGO, other world institution)

9. R \& D (independent, in-house)

10. Consultant

11. Public 
(4) because they have the biggest driver power with the level of dependence toward the subelements of other involved institutions or groups which are the lowest. Then in the second rank are Research \& Development (independent, inhouse) (9), Investor (public, individual, institution) (3), Customer (domestic market, import) (2), Industry (upstream, downstream, supporting) (1), and Educational institution (6), while in third rank it is occupied by Public (11) which is the element with smallest impetus power with the highest level of dependence toward the involved institution or group. The structure of the system of the element of involved institution or group can be seen in Figure 3.

The Figure 3 shows that the level determining of every sub-element is determined from each rank of sub-element. The result of this research is obtained from three hierarchies where the sub-element of Public is on the first level. On the second level, there are the sub-elements of $R \& D$ (independent, in-house) (9), Investor (public, individual, institution) (3), Customer (domestic market, import) (2), Industry (upstream, downstream, supporting) (1), Educational institution (6), Financial institution (bank, non-bank) (7) and Consultant (10). Meanwhile on the third level, it is occupied by the sub-elements of Pressure group (ISPO, NGO, other world instutions) (8), Government (policy, infrastructure, ISPO) (5) and Farmer (self-supporting, plasma, big and small businesses) (4). The third sub-element is the subelement which is affected by direct influence of policy model of SD toward the competitiveness of oil palm industry and will give influence and affect other sub-element.

\section{Element of policy need}

Element of policy need of SD toward the competitiveness of oil palm industry consists of eight subelements i.e. 1). Promotion, advocacy and public

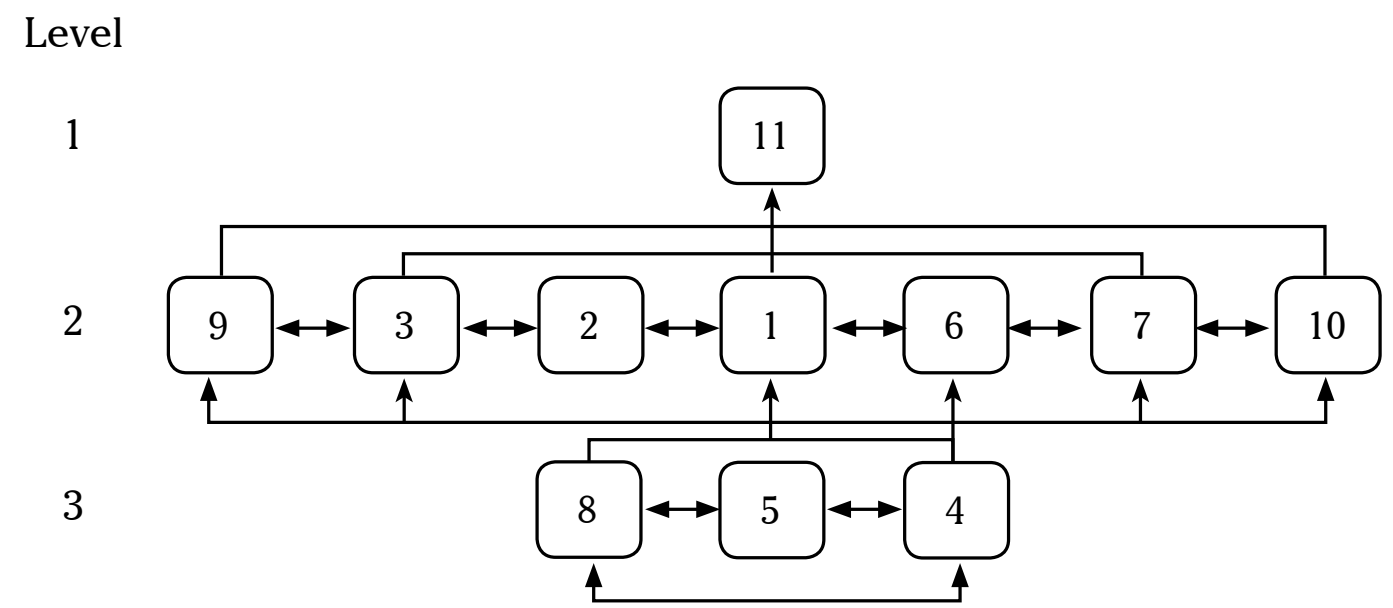

Figure 3. Structure of the system of the element of involved institution/group

Notes :

1. Industry (upstream, downstream, supporting)

2. Customer (domestic market, import)

3. Investor (public, individual, institution)

4. Farmer (self-supporting, plasma, big and small businesses)

5. Government (policy, infrastructure, ISPO)

6. Educational institution
7. Financial institution (bank and non bank)

8. Pressure group (ISPO, NGO, other world institution)

9. R \& D (independent, in-house)

10. Consultant

11. Public 
campaign of oil palm industry, 2). Developement of Human Resources, 3). Product development and increase of added value, 4). Strengthening and law enforcement in the development of sustainable oil palm and permit management, 5). Information transparency of oil palm development, 6). Development of farmer accessibility toward resources, 7). Control of natural forest conversion and turf land, 8). Support of the application of principle and criteria of RSPO, 9). Development of mechanism of the conflict resolution.

In the policy model SD toward the competitiveness of oil palm industry, being the key elements are Promotion, advocacy and public campaign of oil palm industry (1) and Development of Human Resources (2) because having the biggest impeturs power with the level of dependence toward the lowest sub-element of other need. Next the sub-element which is on one level under they are Support of the application of principle and criteria of RSPO (8) and Strengthening and law enforncement in the development of sustainable oil palm and permit management (4). In the third rank, the sub-element including in it is the Control the natural forest conversion and the turf land (7), while the sub-elements which are the fourth rank are Development of the accessibility of farmer toward resources (6), Information transparency of oil palm development (5), Product development and increase of added value (3), and Development of mechanism of the conflict resolution (9). Meanwhile the structure of the system of the element of policy need can be seen in Figure 4.

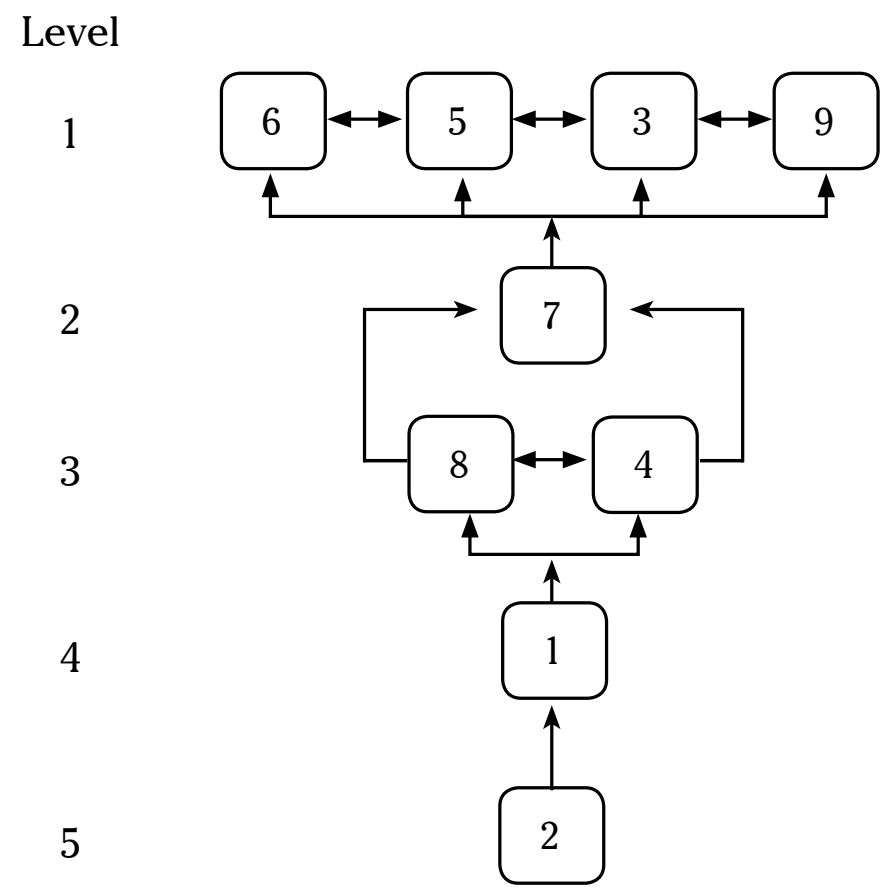

Figure 4. Structure of the system of the element of policy need

Notes :

1. Promotion, advocacy and public campaign of oil palm industry

2. Development of Human Resources

3. Product development and Increase of added value

4. Strengthening and law enforcement in the development of sustainable oil palm and the permit management
5. Transparency of information of oil palm development 6. Development of accessibility of farmer toward resources

7. Control of conversion of natural forest and turf land

8. Support of the application of RSPO principle and criteria

9. Development of mechanism of the conflict resolution 
The Figure 4 shows that the hierarchical levels of the element of policy need consists of four levels, the sub-elements of Development of the accessibility of farmer toward the resources (6), Information transparency of oil palm development (5), Product development and increase of added value (3), and Development of mechanism of the conflict resolution (9). In the second level, there is the sub-element of Control of natural forest conversion and the turf land (7), while on third level, the sub-elements occupying it are Support of the application of principle and criteria of RSPO (8) and Strengthening and law enforcement in the sustainable oil palm development and the permit management (4). Meanwhile in the fourth level, there are the sub-elements of Promotion, advocacy, and public campaign of oil palm industry (1) and Development of Human Resources (2) having the very strong impetus power for other sub-elements. The sub-elements (1) and (2) are the main policy needs, because it will influence the strategy used in relation to SD of oil palm company.

\section{Element of main constraint}

Element of policy need of SD toward the competitiveness of oil palm industry consists of eight sub-elements, i.e. 1). Huge forest deforestation, 2). Threatening the biodiversity wealth on the ecosystem, 3). Increase of global warming, 4). The use of chemical fertilizer to produce the glass house gas emission, 5). Social conflict with the local community, 6). Difficult to get the certificate of RSPO, 7). Upstream industry is difficult to develop, 8). Weakness of law enforcement, 9). Slowness of the certification process of RSPO in Indonesia.

The result of verification in the main constraint model faced to become the key element is Weakness of law enforcement (8), because it has the biggest impetus power with the level of dependence toward the sub-element of other main constraints which is the lowest. It can be said that the main constraint in the policy of SD toward the competitiveness of oil palm industry is the weakness of law enforcement, so that it can cause the policy is not implemented well. Then in the second rank it is Forest deforestation (1). In the third rank, there is Use of chemical fertilizer (4). In the fourth rank, there is the sub-element of Threatening of biodiversity wealth on to the ecosystem (2), while in the fifth rank there are Increase of global warming (3) and Social conflict with local community (5). Meanwhile, in the sixth and seventh ranks there are Difficult to get the certification of RSPO (6), and Upstream industry which is difficult to develop (7). The structure of the system of the element of main constraint can be seen in Figure 5.

Figure 5 shows that the hierarchical level of the element of the constraint consists of seven levels. The sub-element of Upstream industry which is difficult to develop (7) is on the first level. On the second level, it is occupied by the sub-element of Difficult to get the certification of RSPO (6). Meanwhile, on the third level, it is occupied by Increase of global warming (3) and Social conflict with the local community (5). On the fourth and fifth levels it is occupied by the subelements of Threatening the biodiversity wealth on the ecosystem and Use of chemical fertilizer producing the glass house gas emission, while the sixth and seventh levels are occupied by the sub-elements of Huge forest deforestation (1) and Weakness of law enforcement (8). The weakness of law enforcement as the strong impetus power for other sub-elements. The main constraints faced in the policy of sustainable development toward the competitiveness of oil palm industry is. the sub-element of 8 (Weakness of law enforcement). This sub-element is also the influence that appears in the other constraint in this policy.

\section{Element of enabling change}

The element of enabling change consists of 14 sub-elements, i.e.: 1). Forming of ISPO, 2). Increase of production, productivity, and quality of sustainable oil palm plant, 3). Increase income and community welfare, 4). Support development 


\section{Level}

1

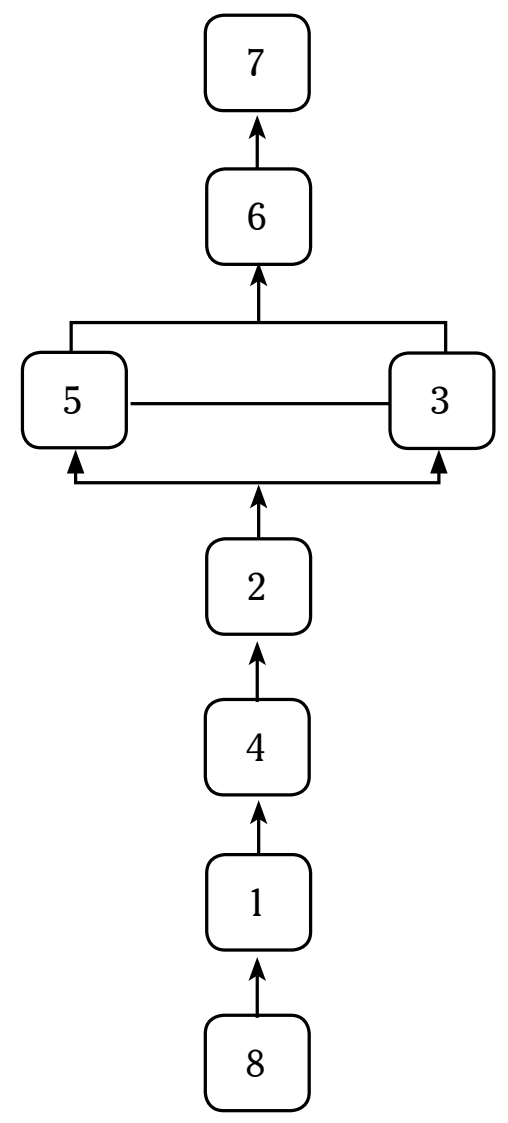

Figure 5. Structure of the system of the element of main constrains

Notes :

1.Huge forest deforestation

2. Threatening the biodiversity wealth in the ecosystem

3. Increase of global warming

5. Social conflict with local community

6. Difficult to get the certification of RSPO

4. Use of chemical fertilizer to produce the gas emission of glass house

7. Upstream industry is difficult to develop

8. The weakness of law enforcement

9. The slowness of RSPO certification process

toward the management of Natural Resources and living environment, 5). Being the member of RSPO, 6). Building the conservation area, 7). Creation of method and system of environmentally friendly, 8). Increase of non-oil and gas foreign exchange, 9). Use of neglected land 10). Development of oil palm commodity, 11). Support increase toward the food security system, 12). Increase of the investment of oil palm business, 13). Development of management information system of plantation, 14). Development of institutional and business partnership.
In the policy model of SD toward the competitiveness of oil palm industry, the enabling change becoming the key is Forming of ISPO (1), because it has the biggest impetus power with the level of dependence toward the sub-element of other change which is the lowest. Then, the sub-element which is on the first level under it, i.e. Increase of production, productivity, and quality of sustainable oil palm plant (2), Support development toward the management of Natural Resources and living environment (4), Developing the conservation area (6), and Creation of method and system of environmentally friendly (7). In the third rank, there are 
sub-elements of Make use of neglected land (9), Development of oil palm commodity (10), Support increase toward the food security system (11) Increase of the investment of oil palm business (12), Development of management information system of the plantation (13) Development of institutional and business partnership (14). In the fourth rank, there is the sub-element of Increase of non-oil and gas foreign exchange (8) and in the fifth rank there are the sub-elements of Increase the income and the community welfare (3). Meanwhile, the structure of the system of the element of enabling change is in Figure 6.
Output of the structural model the element of enabling change with the technique of ISM produces five hierarchical levels. The sub-element of increasing the income and the community welfare (3) is on the first level. The second level is occupied with the sub-element of Increase of nonoil and gas foreign exchange (8), while the third level is occupied by the sub-elements of Making use of neglected land (9), Development of oil palm commodity (10), Increase of support toward the food security system (11) Increase of the investment of oil palm business (12), Development of the management information system of the

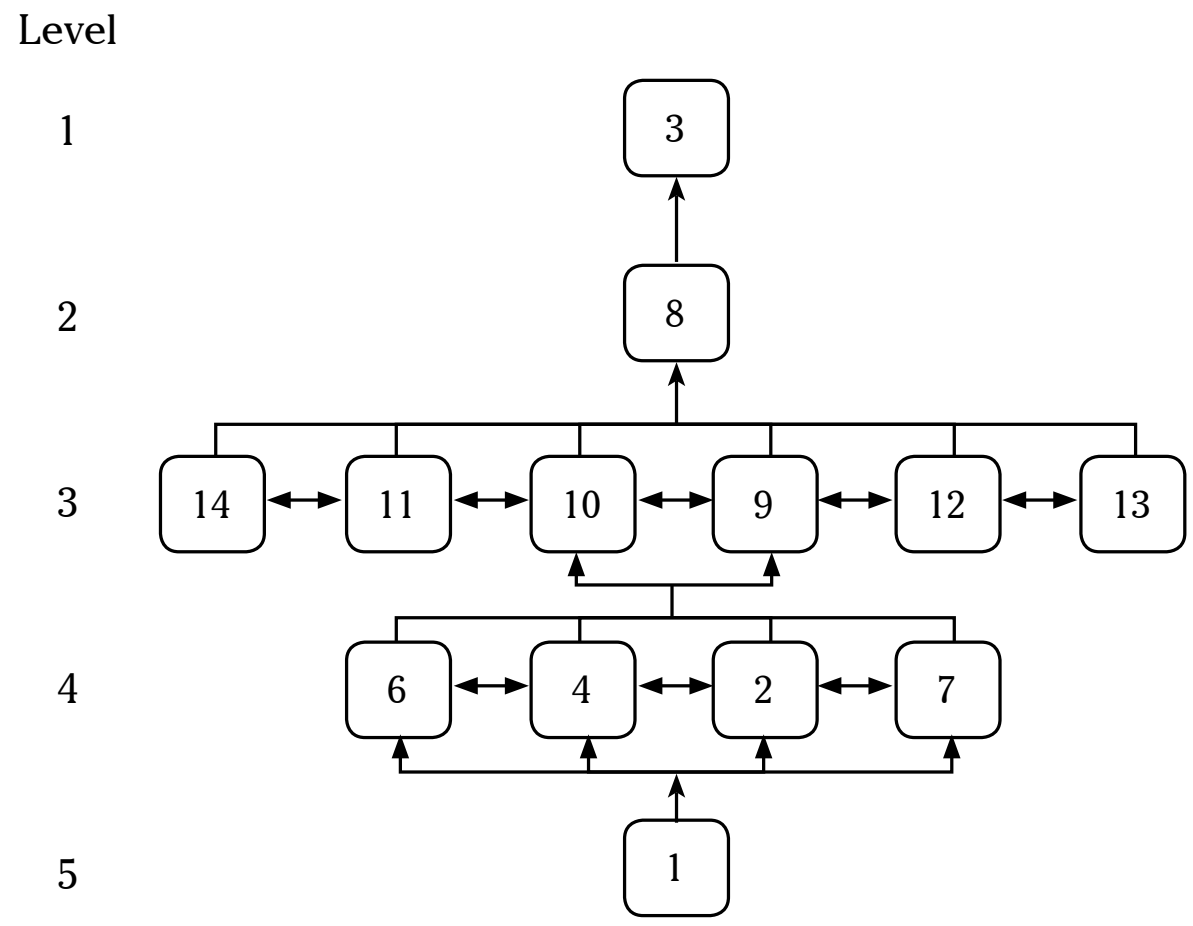

Figure 6. Structure of the element of enabling change

Notes :

1.The forming of ISPO

2.Production increase, productivity, and quality of sustainable oil palm plant

3.Increase the income and the public welfare

4. Development of support toward the management of Human Resources with the living environment

5. Becoming the member of RSPO

6. Developing the conservation area

7. The creation of method and system of environmental friendly
8.Increase of non-oil and gas foreign exchange

9. Use of neglected land

10. Development of oil palm commodity

11. Increase of support toward the food security system

12.Increase of oil palm business investment

13.Development of the information system of plantation management

14. Development of institutional and business partnership 
plantation (13) Development of institutional and business partnership (14). On the fourth level it is occupied by the sub-elements of Increase of production, productivity, and quality of sustainable oil palm plant (2), Development of support toward the management of natural resources and living environment (4), Building the conservation area (6), and Creation of the method and service of environmentally friendly (7), meanwhile the fifth level is occupied by the sub-element of Forming of ISPO (1), this sub-element is enabling change perubahan. With the realization of the change it will trigger the other change (other sub-element).

\section{Objective element}

The objective element of the program consists of five sub-elements i.e., 1). Application of environmentally friendly program in accord with the certification of RSPO, 2). Identifying and explaining the description Identifying and explaining the description of policy in relation to the development of oil palm industry, 3). Analyzing the impact and policy effectiveness of sustainable development toward the competitiveness of the industry, 4). Evaluating the implementation of the sustainable strategy of the policy of RSPO and ISPO, 5). Formulating the business strategy and the policy strategy to reach the sustainable competitive advantage.

In the objective element which becomes the key sub-element is Identifying and explaining the description of policy in relation with the development of oil palm industry (2), because it has the biggest impetus power with the level of dependence toward other sub-element which is the lowest. Next, the sub-element which is on the first level under it is Application of environmentally

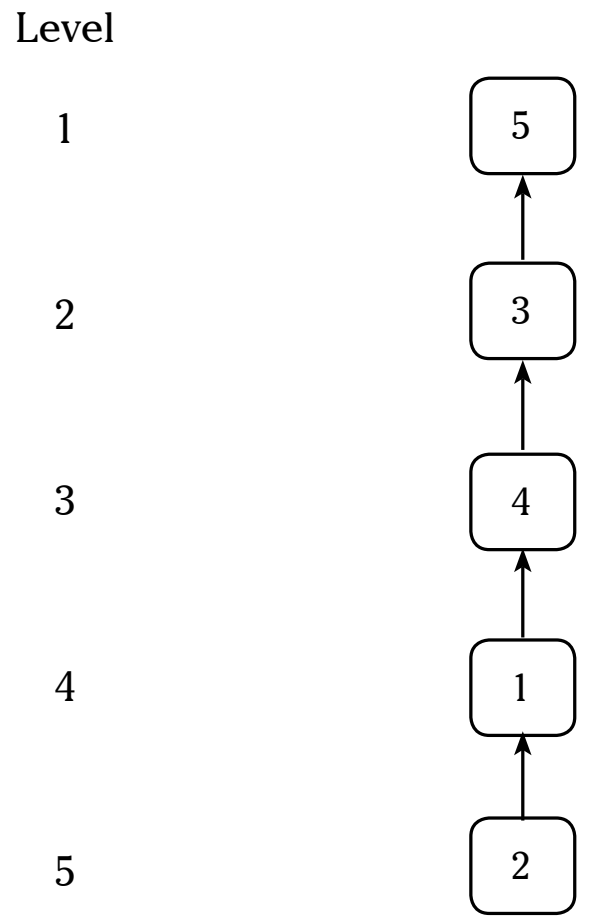

Figure 7. Structure of the system of objective elements

Notes:

1. Application of environmental friendly program in accord with the certification of RSPO

2. Identify and explain the description of policy in relation with the development of oil palm industry
3. Analyze the impact and effectivity of sustainable development policy toward the industry competitiveness

4. Evaluate the implementation of sustainable strategy of the policy of RSPO and ISPO

5 . Formulate the business strategy and the policy to reach the sustainable competitive advantage 
friendly program in accord with the certification of RSPO (1). On the third rank, there is the sub-element of Evaluating the implementation of sustainable strategy of the policy of RSPO and ISPO (4), and on the fourth and fifth ranks, there are Analyzing the impact and policy effectiveness of sustainable development toward the competitiveness of the industry (3) and Formulating the business strategy and the policy strategy to reach the sustainable competitive advantage (5). Figure 7 comes into being the structure of the system for the objective element.

The output of the structural model of the element of program objective with the technique of ISM produces five hierarchical levels. The sub-element of Formulating the business strategy and policy for reaching the sustainable competitive advantage (5) is on the first level. On the second level, it is occupied by the sub-element of Analyzing the impact and policy effectiveness of sustainable development toward the competitiveness of oil palm industry (3). In the third level, it is occupied by the sub element of Evaluating the implementation of sustainable strategy of the policy of RSPO and ISPO (4). Meanwhile in the fourth level, it is occupied by the sub-element of Application of environmentally friendly program in accord with the certification of RSPO (1) and in the fifth level it is occupied by the sub-element of Identifying and explaining the description of policy in relation to the development of oil palm industry (2). Identifying and explaining the description of policy in relation to the development of oil palm industry becomes the main objective of program which is also influencing toward the other program objective (other sub-element).

\section{Element of benchmarks for achieving the goal}

The element of benchmarks for achieving the goal consists of 1). The creation of the trust toward the product, 2). The protection toward the working safety, 3).The creation of prosperous community, 4). The realization of cost efficiency, 5 ). The high working motivation of employee, 6).
The creation of safety in the investment, 7) and The full commitment toward the environmental preservation, 8). The realization of quality preference and moral preference.

In the element of benchmarks for perceiving the goal i.e. the key sub-elements are Full commitment toward the environmental preservation (7) and Protection toward the safety (2). Second rank is the High working motivation of employee (5), The third rank is the Realization of quality preference and moral preference (8), the fourth rank is the Creation of the trust toward the product (1), the fifth rank is the Realization of cost efficiency (4), the sixth rank is the Creation of safety in the investment (6), and the seventh rank is the Creation of prosperous community (3). The structure of the system of benchmarks for achieving the goal can be seen in Figure 8.

The output of the structural model of the element of the program goal with the technique of ISM produces five hierarchical levels. The sub-element of the creation of prosperous community (3) is on level one. Then on level two, it is the sub element of the creation of the security in investment (6). On level three and four, there are sub-elements of the realization of cost efficiency (4) and the creation of trust toward the product (1). On level five and six, there are sub-elements of the Realization of quality preference and moral preference (8) and the high working motivation of employee (5), while in the last level there are sub-elements of Full commitment toward the environmental preservation (7) and Protection toward the working safety (2). The full commitment toward the environmental preservation and the protection toward the work safety become the benchmarks for achieving the goal in the policy model of SD toward the competitiveness of oil palm industry.

\section{Indicator of economic dimension}

The indicator of economic dimension consists of sub-indicators i.e. 1). Quality management, 2). Risks management, 3). Strategic Planning, 4). 


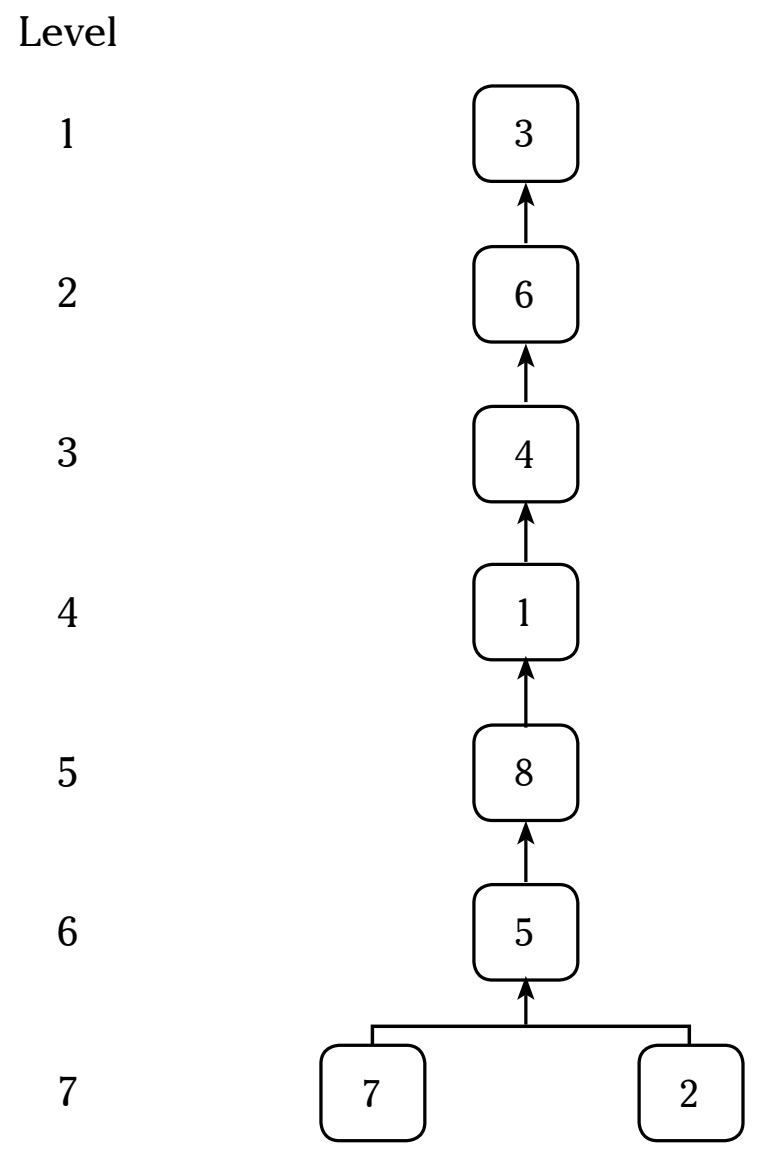

Figure 8. Structure of the element of the benchmarks for achieving the goal

Notes :

1. Creation of trust toward the product

2. The protection toward working safety

3. Creation of prosperous community

4. The realization of cost efficiency
5. High working motivation of employee

6. Creation of safety in the investment

7. Full commitment toward the environment preservation

8 . The realization of quality preference and moral preference
Collaborative partnership, 5). Sharing information, 6). Management of technology, 7). Adoption of security standard, 8). Voice of customer. In the indicator of economic dimension i.e. the key indicators, are Sharing information (5), Managing technology (6) and Voice of customer (8). The three sub-indicators have the very strong impetus power or can act as the activator motor toward other sub-indicators. Besides, the sub-indicator also has the lowest or independent level of dependence. The structure of the system of indicator of the economic dimension can be seen in Figure 9.

The output of the structural indicator model of economic dimension with the technique of ISM produces five hierarchical levels. Sub-indicators of economic dimension are Quality management (1), Risks management (2) which are on level one, then on the level two there is sub-indicator of Strategic planning (3). On level three there is subindicator of Collaborative partnership (4), while on level four there is sub-indicator of Adoption of security standard (7). Meanwhile, on level five there are sub-indicators i.e. Information sharing (5), managing technology (6) and Customer's voice (8).

\section{Indicator of environment dimension}

The environment dimension in the policy of SD toward the competitiveness of oil palm industry consists of fourteen sub-indicators i.e. 1). Adoption 


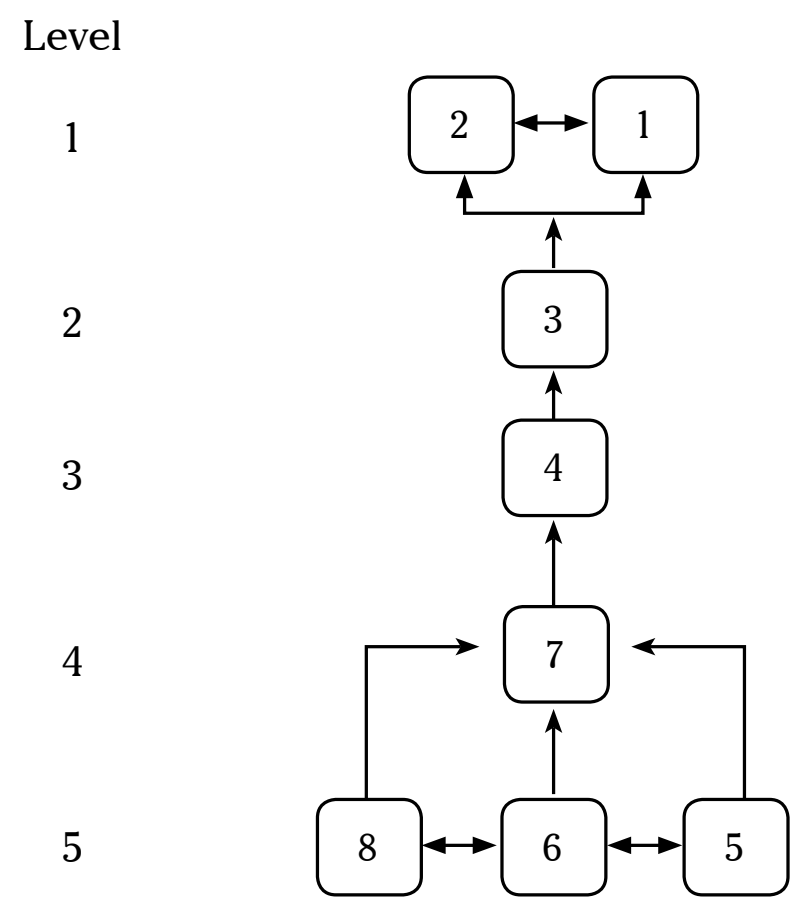

Figure 9. Structure of the system of indicator of the economic dimension

\author{
Notes : \\ 1. Quality Management \\ 2. Risks management \\ 3. Strategic Planning \\ 4. Collaborative Partnership
}

\author{
5. Information Sharing \\ 6. Managing Technology \\ 7. Safety Standard Adoption \\ 8. Consumer's Voice
}

of green practice, 2). Government regulation, 3). Adoption of environmental standard, 4). Voice of customer, 5). Commitment of management, 6). Training of employee, 7). Prize of government and incentive, 8). Risk management, 9). Strategic planning, 10). Collaborative partnership, 11). Information strategy, 12). Management of technology, 13). Management of environmental quality, 14). Adoption of security standard.

The result of verification in the model of environment dimension is the key indicator i.e. Government regulation (2), because it has the very huge impetus power with the level of dependence toward the other lowest environment dimension. It can be said that the environment dimension in the policy of SD toward the competitiveness of oil palm industry is the government regulation, so that in conducting the action it is necessary to be the constitution set. Next, in the second rank it is the voice of customer (4). In the third rank, it is the commitment of management (5). The fourth rank are the information strategy (11) and the management of technology (12). The fifth rank is the collaborative partnership (10). The sixth rank are the strategic planning (9), the risk management (8), the training of employee (6), the management of environmental quality (13), the adoption of security standard (14). Next, the seventh rank is the prize of government and incentive (7), the eight rank is the adoption of environmental standard (3), and the last i.e. the ninth rank is the adoption of the green practice. The structure of the system of indicator of the environment dimension can be seen in Figure 10.

The output of the structural model of the indicator of environment dimension with the technique 


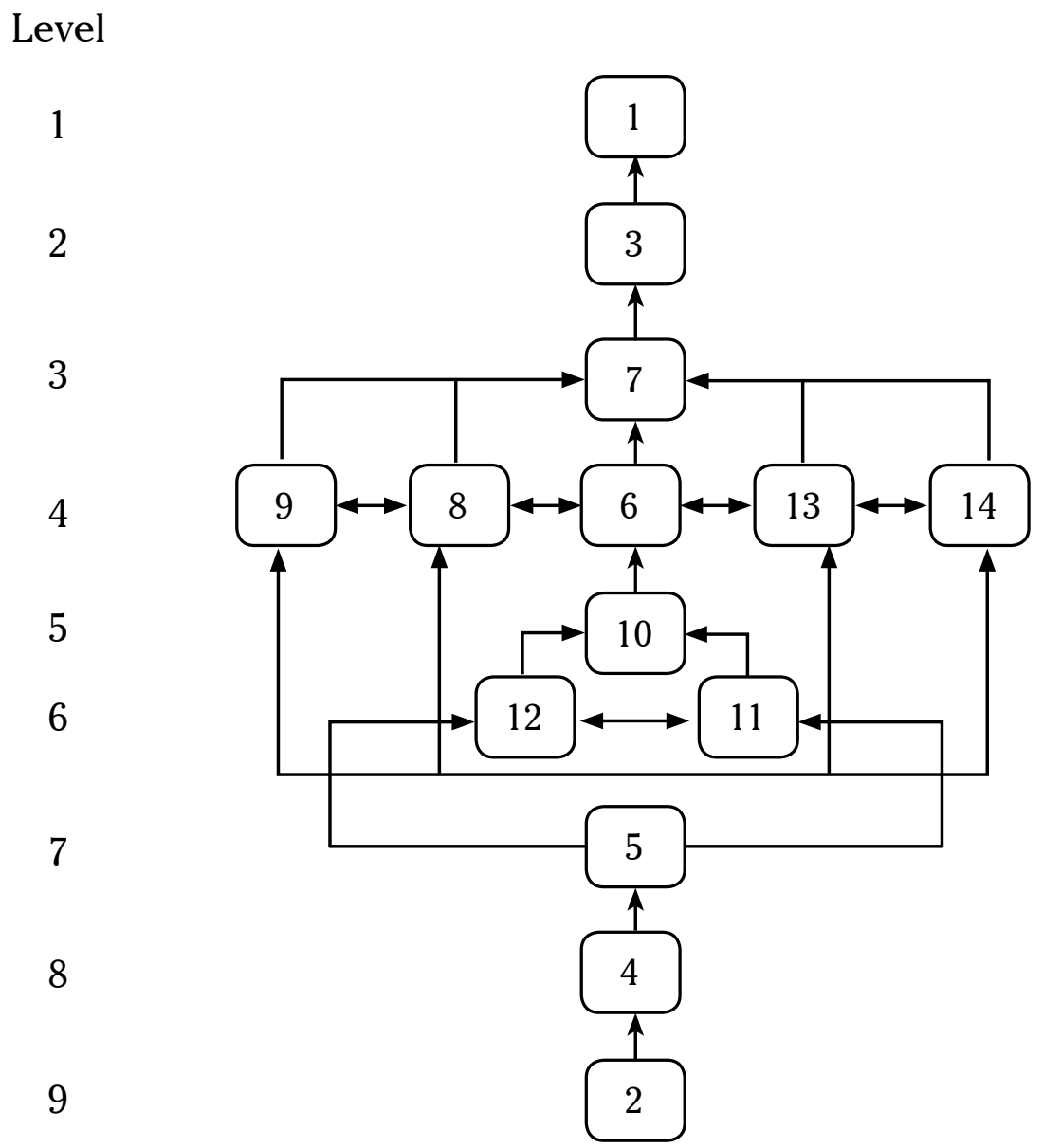

Figure 10. The structure of the social dimension of the indicator system

Notes:

1. Adoption of green practice

2. Government regulation

3. Adoption of environment standard

4. Voice of customer

5. Commitment of management

6. Training of employee

7. Prize of government and incentive
8. Risk management
9. Strategic planning
10. Collaborative partnership
11. Strategy of information
12. Technology management
13. Management of environment quality
14. Adoption of safety standard

of ISM produces nine hierarchical levels. Subindicator of economic dimension, Adoption of green practice (1), is on level one. On level two there is sub-indicator of Adoption of environmental standard (3), while on level three there is subindicator of Prize of government and incentive (7). On level four there are sub-indicators of Training of employee (6), Risk management (8), Strategic planning (9), Management of environmental quality (13) and Adoption of security standard
(14). On level five there is sub-indicator of Collaborative partnership (10), on level six there are sub-indicators of Information strategy (11) and Management of technology (12). Meanwhile, on level seven, eight and nine there are management's commitment sub-indicator (5), Voice of customer, (4) and Government regulation (2).

\section{Indicator of social dimension}

Social dimension in the policy of SD toward the 
competitiveness of oil palm company consists of twelve sub-indicators, i.e. 1). Equity of labor, 2 ). Health of employee, 3). Protection of injured employee, 4). Generosity, 5).Living quality, 6). Exempting the public room, 7). Voice of customer, 8). Adoption of security standard, 9). Government regulation, 10). Management of technology, 11). Strategic planning, 12). Collaborative partnership.

The result of verification in the social dimension model faced which is the key indicator is the government regulation (9), because of having the very huge impetus power with the level of dependence to the other social dimension which is the lowest. It can be said that the social dimension in the policy of SD toward the competitiveness of the oil palm industry is by the government regulation, so that in doing the action it is necessary to be paid attention to the constitution set. Next in the second rank there are the voice of customer (7), the adoption of security standard (8), and the management of technology (10). In the third rank there is sub indicator of the strategic planning (11), while the fourth rank are to exempt the public room (6), the protection of injured employee (3), the health of employee (2), and the collaborative partnership (12). Next, the sixth rank are living quality (5) and generosity (4), the seventh rank is the last rank from the social dimension which is the equity of labor (1). The structure of the system of social dimension can be seen in Figure 11.

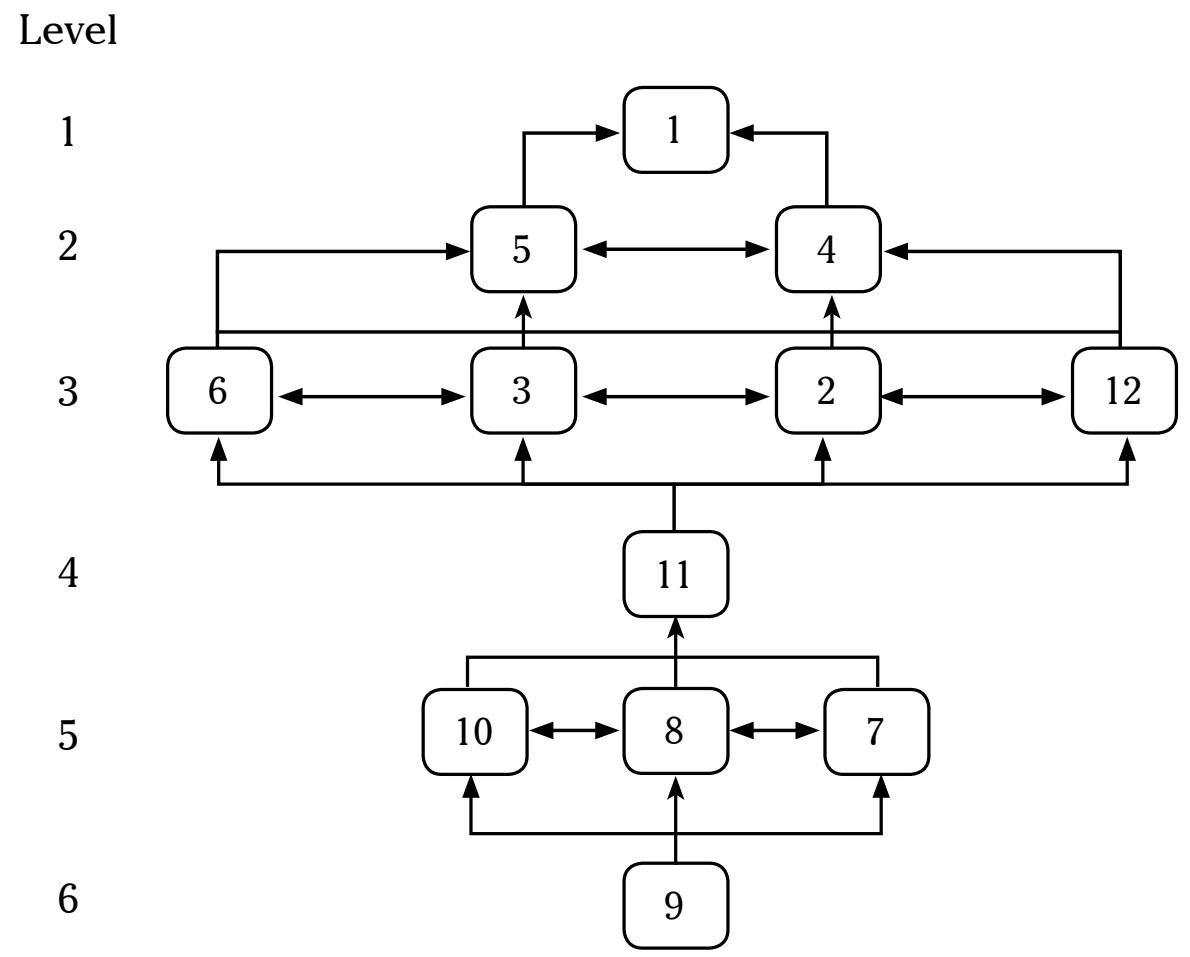

Figure 11. Structure of the indicator system of the social dimension

Notes:

1. Labor equity

2. Health of employee

3. Protection of injury employee

4. Philanthropy

5. Living quality

6. Exempt the public room
7. Voice of customer

8. Adoption of safety standard

9. Government regulation

10. Management of technology

11. Strategic planning

12. Collaborative partnership 
Table 2. ISM Overall analysis result

\begin{tabular}{|c|c|c|c|}
\hline \multicolumn{4}{|c|}{ ISM Technique } \\
\hline Element & Key Sub-Element & Linkage Sub-Element & Influenced Sub-Element \\
\hline $\begin{array}{l}\text { Influenced } \\
\text { institution / group }\end{array}$ & $\begin{array}{l}\text { 5.Government (policy, } \\
\text { infrastructure, ISPO) }\end{array}$ & $\begin{array}{l}\text { 1.Industry (upstream, } \\
\text { downstream, supporting) } \\
\text { 2. Customer (domestic market, } \\
\text { import) } \\
\text { 3.Investor (public, individual, } \\
\text { institution) } \\
\text { 7. Financial institution (bank, } \\
\text { non-bank) } \\
\text { 8. Pressure group (ISPO, NGO, } \\
\text { other world institutions) }\end{array}$ & $\begin{array}{l}\text { 4. Farmer (self-supporting, plasma, } \\
\text { big and small businesses) } \\
\text { 6. Educational institution } \\
\text { 9. R \& D (independent, in-house) }\end{array}$ \\
\hline $\begin{array}{l}\text { Involved institution } \\
\text { / group }\end{array}$ & $\begin{array}{l}\text { 4. Farmer (self-supporting, } \\
\text { plasma, big and small } \\
\text { businesses) } \\
\text { 5. Government (policy, } \\
\text { infrastructure, ISPO) } \\
\text { 8. Pressure group (ISPO, } \\
\text { NGO, other world } \\
\text { institutions) }\end{array}$ & $\begin{array}{l}\text { 1.Industry (upstream, } \\
\text { downstream, supporting) } \\
\text { 2. Customer (domestic market, } \\
\text { import) } \\
\text { 3.Investor (public, individual, } \\
\text { institution) } \\
\text { 6. Educational institution } \\
\text { 7. Financial institution (bank, } \\
\text { non-bank) } \\
\text { 9. R\&D (independent, in-house) } \\
\text { 10. Consultant }\end{array}$ & 11. Public \\
\hline Policy need & $\begin{array}{l}\text { 1. Promotion, advocacy } \\
\text { and public campaign of } \\
\text { oil palm industry } \\
\text { 2. Development of HR } \\
\text { 4. Strengthening and law } \\
\text { enforcement in the oil } \\
\text { palm development } \\
\text { 8. Stimulus of the } \\
\text { application of RSPO P\&C }\end{array}$ & $\begin{array}{l}\text { 7. Control of the conversion of } \\
\text { old forest and turf land }\end{array}$ & $\begin{array}{l}\text { 3. Product development and the } \\
\text { increase of added value } \\
\text { 5. Transparency of the information of } \\
\text { oil palm development } \\
\text { 6. Development of the accessibility } \\
\text { of farmer toward resources } \\
\text { 9. Development of the mechanism of } \\
\text { conflict resolution }\end{array}$ \\
\hline Main constraints & $\begin{array}{l}\text { 1. High deforestation } \\
\text { 2. Threatening the } \\
\text { biodiversity wealth in } \\
\text { the ecosystem } \\
\text { 4. The use of chemical } \\
\text { fertilizer that produce } \\
\text { emissions } \\
\text { 8. Weakness of the law } \\
\text { enforcement }\end{array}$ & $\begin{array}{l}\text { 7. Upstream industry is difficult } \\
\text { to develop }\end{array}$ & $\begin{array}{l}\text { 3. Increase of global warming } \\
\text { 5. Social conflict with the local } \\
\text { community } \\
\text { 6. It is difficult to get the RSPO } \\
\text { Certification } \\
\text { 9. Slow RSPO certification process in } \\
\text { Indonesia }\end{array}$ \\
\hline $\begin{array}{l}\text { Element of enabling } \\
\text { change }\end{array}$ & $\begin{array}{l}\text { 1. The forming of ISPO } \\
\text { 2. Production increase, } \\
\text { productivity, and quality } \\
\text { of oil palm plant } \\
\text { 4. Support development } \\
\text { toward the management } \\
\text { of natural resources and } \\
\text { infrastructure } \\
\text { 5. Becoming the member } \\
\text { of RSPO } \\
\text { 6. Building the } \\
\text { conservation area } \\
\text { 7. Creation of method } \\
\text { and system which is } \\
\text { environmental friendly }\end{array}$ & $\begin{array}{l}\text { 9. Make use of the neglected } \\
\text { land } \\
\text { 10.Development of oil palm } \\
\text { commodity } \\
\text { 11. Support increase toward the } \\
\text { food security system } \\
\text { 12. Investment increase of oil } \\
\text { palm business } \\
\text { 13.Development of } \\
\text { management information } \\
\text { system } \\
\text { 14.Development of business } \\
\text { institutional and } \\
\text { partnership }\end{array}$ & $\begin{array}{l}\text { 3. Increase the income and welfare } \\
\text { of community } \\
\text { 8. Increase of non-oil foreign } \\
\text { exchange }\end{array}$ \\
\hline
\end{tabular}




\begin{tabular}{|c|c|c|c|}
\hline \multicolumn{4}{|c|}{ ISM Technique } \\
\hline Element & Key Sub-Element & Linkage Sub-Element & Influenced Sub-Element \\
\hline Objective element & $\begin{array}{l}\text { 1. Application of } \\
\text { environmental friendly } \\
\text { program in accord with } \\
\text { the certification of ISPO/ } \\
\text { RSPO }\end{array}$ & $\begin{array}{l}\text { 2.Identify and explain the } \\
\text { description of \policy related } \\
\text { to the development of oil } \\
\text { palm industry } \\
\text { 3. Analyze the impact and the } \\
\text { effectiveness of policy of the } \\
\text { sustainable development } \\
\text { toward the competitiveness } \\
\text { of company }\end{array}$ & $\begin{array}{l}\text { 4. Evaluate the implementation of } \\
\text { sustainable strategy of the policy } \\
\text { of RSPO and ISPO } \\
\text { 5. Formulate the business strategy } \\
\text { and the policy strategy to reach } \\
\text { the sustainable competitive } \\
\text { advantage }\end{array}$ \\
\hline $\begin{array}{l}\text { Element of } \\
\text { benchmarks for } \\
\text { achieving the goal }\end{array}$ & $\begin{array}{l}\text { 7. Full commitment toward } \\
\text { the environmental } \\
\text { preservation }\end{array}$ & $\begin{array}{l}\text { 2. Protection toward the } \\
\text { working safety } \\
\text { 3. Creation community wealth } \\
\text { 4. Realization of cost efficiency }\end{array}$ & $\begin{array}{l}\text { 1. Creation of trust toward product } \\
\text { 5. High working motivation of } \\
\text { employee } \\
\text { 6. Creation of the security in } \\
\text { investment } \\
\text { 8. Realization of quality preference } \\
\text { and moral preference }\end{array}$ \\
\hline $\begin{array}{l}\text { Indicator of } \\
\text { economic } \\
\text { dimension }\end{array}$ & $\begin{array}{l}\text { 5. Sharing information } \\
\text { 6. Management of } \\
\text { technology } \\
\text { 8. Voice of customer }\end{array}$ & 7. Adoption of security standard & $\begin{array}{l}\text { 1. Quality management } \\
\text { 2. Risk management } \\
\text { 3. Strategic planning } \\
\text { 4. Collaborative partnership }\end{array}$ \\
\hline $\begin{array}{l}\text { Indicator of } \\
\text { environmental } \\
\text { dimension }\end{array}$ & $\begin{array}{l}\text { 2. Government regulation } \\
\text { 4. Voice of customer } \\
\text { 5. Management } \\
\text { Commitment } \\
\text { 10. Collaborative } \\
\text { partnership } \\
\text { 11. Sharing information } \\
\text { 12. Management of } \\
\text { technology }\end{array}$ & $\begin{array}{l}\text { 6. Training of employee } \\
\text { 8. Risk management } \\
\text { 9. Strategic planning } \\
\text { 13. Management of } \\
\quad \text { environmental quality } \\
\text { 14. Adoption of security } \\
\quad \text { standard }\end{array}$ & $\begin{array}{l}\text { 1. Adoption of green practice } \\
\text { 3. Adoption of environmental } \\
\text { standard } \\
\text { 7. Government prize and incentive }\end{array}$ \\
\hline $\begin{array}{l}\text { Indicator of social } \\
\text { dimension }\end{array}$ & $\begin{array}{l}\text { 7. Voice of customer } \\
\text { 8. Adoption of security } \\
\text { standard } \\
\text { 9. Government regulation } \\
\text { 10. Management of } \\
\quad \text { technology } \\
\text { 11.Strategic planning }\end{array}$ & $\begin{array}{l}\text { 2. Health of employee } \\
\text { 3. Protection of employee's } \\
\text { injury } \\
\text { 6. Exempt of public room } \\
\text { 12. Collaborative partnership }\end{array}$ & $\begin{array}{l}\text { 1. Equity of worker } \\
\text { 4. Philanthropy } \\
\text { 5. Living quality }\end{array}$ \\
\hline
\end{tabular}

Based on Table 2, it can be said that the element of enabling change for the policy of sustainable development toward the competitiveness of oil palm company is the forming of ISPO, the production increase, the productivity and the sustainable quality of oil palm plant, the development of support toward the management of human resources and living environment, the developing of conservation area, and the creation of method and system which is environmental friendly. The thing is almost the same with the research done by Indriantoro (2010) that his research result states that through the application of environmental friendly program realized in the certification of RSPO, where in the research result it is mentioned that the company is expected to be able to provide training, guidance or application of environmentally friendly program to the plasma farmer. In the research, it is also explained some efforts to improve the quality and the productivity of the palm oil production through the application of environmentally friendly program, which are: a). Comply with the laws and the national and international regulations which are in accord with and have been ratified; b). Conduct the campaign of the role of the oil palm plantation in the contribution of carbon sequestration and oxygen provider; c). Implement the appropriate 
operating procedures and consistently monitored. Arip et al. (2013) revealed that as the biggest producer of palm oil, the two countries (Indonesia and Malaysia) should pay more attention to the development of downstream industry which also takes advantage from the comparative advantage owned by the upstream industry.

The result of ISM as a whole in Table 2 shows that the policy which is the key factor of the increase of competitiveness of the sustainable oil palm industry to the future should be oriented to the environmental and social aspects. In this time the industry is still more orienting to the economic aspect, so that the social and environmental aspects get priority which is fewer compared to the economic aspect. So that it can be concluded that based on the results of ANP and ISM, the policy related to the development of oil palm industry in order to be competitive and sustainable should really apply the principles of sustainable development, i.e. the balance of social, economic and environmental aspects. This is relevant with the concept of WBCSD (2010), in order the oil palm industry can be competitive and sustainable, it should apply the inclusive business, i.e. still having high economic benefits so that it can push and increase the contribution of social aspect and maintain as well as repair the preservation of living environment (Virginie and Veglio 2011). In contrast with a sustainable environment and having the high social-economic impact, the certainty and sustainability of any business can be reached. Further, Obidzinski et al. (2012) recommended to the government, the industrial leader, and the civil society organization for: 1. Future plantation development targets come from the non-forest land, 2. Evaluating the plant life cycle cost, 3. Excluding the deforestation from the rules in order to be no more logging, 4. Enforcing the regulation and standard, 5. Observing and mediating the community negotiation with the company more actively, 6. Obeying the industrial standard, 7. Enforcing and monitoring the labor regulations, 8. Strengthening the right on indigenous land.
Besides, the oil palm industry to the future in order to have the sustainable competitiveness needs to apply the innovation of green technology developed to be one of the expansions of research of the technological innovation based on the ecological and economic regulations. This will also give an impact to Business Continuity Management (BCM) and the use of green technology used in BCM has made a new concept of Green Business Continuity Management (Gang 2010).

The overall result of ISM clearly shows that the government policy is the factor which is considered to be the most influential toward the competitiveness of sustainable oil palm industry, both from the law enforcement (community protection and investment protection) and the application of ISPO (as the reflection of the policy which has the social and environmental orientation). Van Rooyen et al. (2011) stated the regulation and the supported government policy is very relevant to the competitive industrial performance. Thus it is expected that the policy of Indonesian government to the future can push and support, even fully advocate the development of domestic oil palm industry to keep increasing the competitiveness of sustainable oil palm industry.

\section{MANAGERIAL IMPLICATIONS}

Based on the research result, the description of policy related to the development of oil palm industry and its implementation in some companies in Indonesia is still more likely for the importance of the economic aspect compared to the social and environmental aspects. We can see that the most consistent policy of Government is what is in relation with Exit Duty (Bea Keluar/ BK) of the export of oil palm product which since 1998 should be applied with various scenarios. BK first was known with the term of Export Tax (PE), then it was changed to become Export Retribution (PE) and since 2007 up to now was known with Exit Duty (BK). Hasan et al. (2001) in his research showed that the imposition of export tax would cause the negative impact which was in the 
long run toward the competitiveness of oil palm industry in Indonesia.

The main goal of the imposition of $\mathrm{BK}$ is to get the very huge foreign exchange from the profit of oil palm industry making sure the stability of the domestic cooking oil selling price. Then with the last scenario, it is expected that BK can push the creation of strong downstream industry but unfortunately with huge sacrifice in the upstream sector. On the other side, with the principle of government budget, the government income which is very huge from BK does not mean to be able to be directly re-allocated to the oil palm industry, especially in the upstream sector (plantation and farmer). The result of BK allocated for the replanting fund for example is not allocated well. Whereas, the amount of smallholder's estate which should be rejuvenated has been very huge. The rejuvenation of smallholder's estate is one of key factors of the national oil palm plantation productivity. With the area reaching $43 \%$ and the quality of plantation and seed which is not good, the rejuvenation is the thing which is absolutely must be done. In 2012, the Association of Oil Palm Farmer in Indonesia (APKASINDO) had ever proposed the rejuvenation fund request coming from BK for about $1,000,000$ (a million) Ha of people oil palm plantation.

The mandate of biodiesel use from oil palm which is proclaimed by the government is also having the impression of half-hearted. At this moment, almost all producers of biodiesel cannot get the use of economy which is suitable on the product. This is caused by the stipulation of Ministry of EHR which is not precise during this time. Whereas, the substantial need of diesel/biodiesel fuel is come from across industries and the mining in general. Kierulff (2011) stated that the biodiesel industry should run sustainably, contributing the sustainable development to the entire stakeholders depending to the responsible company operation. Therefore, the industry and the government should try to seek the new innovation to be able to handle this condition by paying attention to the economic, social, environmental aspects.

The existing policies not fully support the competitiveness of sustainable oil palm. This is seen from the key factor of the element of policy of the result of ISM which is still dominated by the government problem (policy), the law enforcement and the regulation. Ideally, the Indonesian government policy should support and protect as well as fully back-up the national oil palm industry, especially from the international non tariff barrier attack and negative campaign. On the other side, the problem handled by the industrial party should only be able to be handled by the industry itself. For example, the negative campaign of environmental damage due to deforestation which is caused by the land conversion on the development of oil palm plantation is not in serious condition as being accused during this time. Because based on the data of the rate of change of total forest in Indonesia since 2004 until now, it is not changed significantly, but it adds mainly on the protected forest and the wildlife reserve. Meaning that the development of oil palm plantation during this time is more on the degraded forest and other uses forest which comply with forest regulation.

This becomes the core of the whole managerial implication of this research which is increases the productivity of plantation to the higher level by minimizing the sacrifice from the social and environmental sides. The potential productivity of the oil palm plantation which can exceed 5 ton per hectare per year gives a very clear description that the expansion of the oil palm plantation hectarage is not the key factor of production growth. To reach the productivity, it is necessary to have new high yielding clones, consume less ground water, less chemical fertilizer application, and have shorter immature period of and longer productive age. This can only be obtained from consistent and sustainable research and development (R\&D).

$R \& D$ in the field of oil palm germination needs a long time to be able to reach the commercial 
scale (15 - 25 years). This should be done by all stakeholders on industry, government, academician and NGO. The collaboration pattern (Business - Government - Academic - NGO) should be programmed well and implemented consistently to reach the maximum result. The industry has capacity to allocate some part of the plantation to be used for developing the seed garden, the government has the enormous fund collected from export tax over the years, Academician has the competent researcher and knowledge, and NGO has a very strong sensitivity on the issues of social and environment. The breakthrough of this collaboration will be a big step toward the highly competitive and sustainable Indonesia oil palm industry.

Strategy, policy and efforts done by a number of big companies of oil palm to reach the superior productivity should be able to be made the role model for all actors of oil palm plantation business. In principle, if the quality of seed, the class of land, the climate and the quality of plantation management can be parallelized with the big plantation, the smallholder's plantation is able to produce in higher result.

Seeing that we still have big area for the improvement of smallholder's plantation, the high productivity of this sector is the main indicator in the creation of superior performance sustainable development aspects. The smallholder's plantation should be the main focus in pushing the rapid growth of productivity; this can be done together by the corporations and other stakeholders in the partnership/collaborative system.

Those facts shows that the concept of oil palm industry's sustainable competitiveness concept is a system that involves the entire stakeholders by utilizing the superiority and the opportunity to improve the productivity focused on the smallholder's plantation and raise the welfare of surrounding community as well as to maintain the balance of living environment. Righarts
(2009) stated that to increase the productivity of smallholders, it is necessary to have the network innovation in form of knowledge transfer, financial advice and support as well as tangible support. The availability of innovation for the development of smallholder's that focus on result, functional, and economically feasible will erase the poverty (Obire and Putheti 2010).

This strengthens the concept of Creating Shared Value (CSV) having the orientation toward the social aspect around the industry and the commitment toward the management of sustainable environment. The increase of production obtained from the growth of throughput per hectare will give an impact for a longer time. The productivity can also be seen from the growth of throughput related to the time dimension. New clones which can be started to produce faster and can be still feasible to produce in the longer time will give the value advantage for this industry.

When the volume of production of the smallholder's significantly increases above the competitor, the market share will increase, on the other hand throughput per hectare which is high will lower the unit cost, thus the profit margin will be better. The ideal condition is the main foundation to achieve the sustainable competitive advantage.

\section{CONCLUSION}

\section{Conclusions}

- Strategy and policy of oil palm industry convinced should pay attention to the environmental aspect and the social aspect in the first position. The current superior economic aspect should support the social and environmental aspects.

- Aspects of environmental, social and role of government/regulation become the main driven factor in determining the strategy of sustainable development to support the competitiveness of oil palm industry in Indonesia. 


\section{Further Research}

From this research result, it is necessary to have the further research to seek the ideal form of the collaboration pattern, Government - Industry -
Academician and NGO in pushing the increase of productivity and the development of people oil palm plantation.

\section{REFEREN CES}

Anderson DA. (2010). Environmental Economics and Natural Resource Management. $3^{\text {rd }}$ edition. Routledge. USA.

Arip MA, Yee LS, Feng TS. (2013). Assessing the Competitiveness of Malaysia and Indonesia Palm Oil Related Industry. World Review of Business Research Vol. 3. No. 4. November 2013 Issue. pp. 138 - 145.

Blackburn WR. The Sustainability Handbook, The Complete management Guide to Achieving Social, Economic and Environmental Responsibility. (2007) (e-book). Earthscan. Washington DC. USA.

[Ditjenbun] Direktorat Jenderal Perkebunan. (2013). Perkembangan Produksi Komoditi Perkebunan 2008 - 2013.

Elkington JB. (1997). Cannibal with Forks, the Tripple Bottom Line of Twentieth Century Business, Capstone Publishing Ltd, London.

Elliott JA. An Inroduction to Sustainable Development. $3^{\text {rd }}$ Ed. (2006) (e-book). Routledge. New York. USA.

Eriyatno, Fadjar S. (2007). Riset Kebijakan: metode penelitian untuk pascasarjana. Bogor: IPB Press.

[FAO] Food and Agriculture Organization of the United Nations. (2006). [http://www.fao.or accessed in November 2013].

Fritz M. and Schiefer G. (2008). Sustainability in Food Network. [GEWISOLA] German Association of Agricultural Economics. Germany: University of Bonn.

Fritz T. The Competitive Advantage Period and the Industri Advantage Period, Assessing the Sustainability and Determinants of Superior Economic Performance. (2008) (e-book dissertation). Gabler Edition Wissenschaft.Weisbaden. Germany.

Goenadi. (2008). Perspective on Indonesian Palm Oil Production. Paper of International Food and Agriculture Trade Policy Council. Bogor. Indonesia.

Greenpeace. (2010). [Internet] accessed in 2013 November 4. Available on http://www.greenpeace.org.

Hasan MF, Reed MR, Marchant MA. 2001. Effects of an Export Tax on Competitiveness: The Case of the Indonesian Palm Oil Industry. Journal of Economic Development. 26(2) 77.

Hardi PZ and T. Assessing Sustainable Development: Principles in Practice. (1997) (e-book). International Institute for Sustainable Development. Winnipeg. Canada.

Haryana, Arif and friends. (2010). Naskah Kebijakan (Policy Paper): Kebijakan dan Strategi dalam Meningkatkan Nilai Tambah dan Daya Saing Kelapa Sawit Indonesia Secara Berkelanjutan dan Berkeadilan. Directorate for Food and Agriculture. Ministry of National Development Planning / National Development Planning Bureau (BAPPENAS).

Herianto. (2008). Analsis Daya Saing Industri Kelapa CPO Indonesia di Pasar Internasional [Thesis]. Bogor: Sarjana Program of Agribusiness Management Extension, Faculty of Agriculture, Bogor Agricultural University.

Holmberg J. (1992), Making Development Sustainable: Redefining Institutions, Policy, and Economics, Washington, D.C.: Island Press.

[ISPO] Indonesian Sustainable Palm Oil System. (2013). Daftar perusahaan kelapa sawit yang telah bersertifikat [Internet] accessed in 2013 October. Available on http://www.ispo-org.or.id.

Indriantoro FW. (2010). Analisis Rantai Nilai Produksi Minyak Sawit Berkelanjutan (Studi Kasus PT. Hindoli di Kabupaten Musi Banyuasin Propinsi Sumatera Selatan). [Thesis] Postgraduate Program of Bogor Agricultural University.

Kane, G. (2010). The Three Secrets of Green Business: Unlocking Competitive Advantage in a Low Carbon Economy. Earthscan. USA

Kierulff JM. (2011). Does the Biofuel Industry, with The Aid of Certification Programs, Contribute to Sustainable Development? [Dissertation]. Mississipi (US): The University of Southern Mississipi.

LMC International. (2011).Perbandingan biaya produksi riil negara penghasil utama CPO (US\$ per ton CPO).

Obidzinski K, Andriani R, Komarudin H, Andrianto A. (2012). Environmental and Social Impacts of Oil Palm Plantations and Their Implications for Biofuel Production in Indonesia. Ecology and Society. 17(1): 1 - 19.

Obire O. Putheti RR. (2010). The Oil Palm Tree: A Renewable Energy in Poverty Eradication in Developing Countries. Drug Invention Today. Vol 2 (1): 34-41. 
Oil World. (2009). Oil World Annual 2009. ISTA Mielke GmbH. Lengenberg, Hamburg. Germany.

Oil World. (2014). Oil World Annual 2014. ISTA Mielke GmbH. Lengenberg, Hamburg. Germany.

Manggabarani. A. (2010). Memaknai Sebuah Anugrah: Sumbangsih Kelapa Sawit Indonesia bagi Dunia. Ditjenbun, Department of Agriculture of Republic of Indonesia.

Rifin A. (2010). An Analysis of Indonesia's Palm Oil Position in the International Market.Oil Farm Industri Economic Journal Vol 10 (1). pp: 35-42.

Righarts AMT. (2009). Partnership for Sustainable Agriculture and Poverty Reduction in Africa [Dissertation]. (ND). The Netherlands Open University.

Robertson G.P. and S. M. Swinton. (2005). Reconciling agricultural productivity and environmental integrity: a grand challenge for agriculture. Front EcoEnvironment, Vol 3, No. 1, pp: 38-46.

[RSPO] Roundtable on Sustainable Palm Oil. (2011). [Internet] accessed in 2013 October. Avaiable at http://www.rspo.org.

Saragih B. (2010). Agribisnis: Paradigma Baru Pembangunan Ekonomi Berbasis Pertanian. IPB Press. Bogor

Strange T. Bayley A. Sustainable Development, Linking Economy, Society, Environment. (2008) [e-book] . OECD.

[TAMSI-DMSI] Tim Advokasi Minyak Sawit Indonesia-Dewan Minyak Sawit Indonesia. (2010). Fakta Kelapa Sawit Indonesia. TAMSI - DMSI (ID).

Van Rooyen J, Esterhuizen D, Stroebel L. (2011). Analyzing the Competitive Performance of the South African Wine Industry. International Food and Agribusiness Management Review. 14(4): 179-200.

Virginie B, Veglio F. (2011). Inclusive Business for Sustainable Livehood. Field Actions Science Reports. Vol (5): 1-5.

[WBCSD] World Business Council for Sustainable Development. (2008). Inclusive Business: Profitable business for successful development. Genewa (CH): World Business Council Sustainable Development. 